Relations industrielles

Industrial Relations

\title{
Conciliation Statistics
}

\section{Denys Dion}

Volume 6, numéro 3, juin 1951

URI : https://id.erudit.org/iderudit/1023228ar

DOI : https://doi.org/10.7202/1023228ar

Aller au sommaire du numéro

Éditeur(s)

Département des relations industrielles de l’Université Laval

ISSN

0034-379X (imprimé)

1703-8138 (numérique)

Découvrir la revue

Citer ce document

Dion, D. (1951). Conciliation Statistics. Relations industrielles / Industrial

Relations, 6(3), 94-95. https://doi.org/10.7202/1023228ar

Tous droits réservés @ Département des relations industrielles de l’Université Laval, 1951

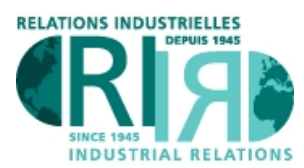

INDUSTRIAL RELATIONS
Ce document est protégé par la loi sur le droit d'auteur. L’utilisation des services d'Érudit (y compris la reproduction) est assujettie à sa politique d'utilisation que vous pouvez consulter en ligne.

https://apropos.erudit.org/fr/usagers/politique-dutilisation/ 


\section{A guarantee of the Act}

Is it possible to live in idleness and draw unemployment insurance benefits?

From the start, Parliament was careful to make sure that those who claim benefits must first prove that they belong to the labour market; i.e., that they have worked recently a substantial number of days in insurable employment.

The Commission is not satisfied to know that a man has worked at some time or other in the past, or has recently worked for a short period.

The insured unemployed worker must show that he has contributed at least 180 times to the insurance fund in the last two years. That means having worked at least 180 days.

Of the 180 contributions, at least 60 must have been made within a' year or 45 within six months; i.e., evidence must be shown of a substantial and recent work history.

The seasonal character of a large fraction of our economy inevitably forces considerable time losses upon many workers. If there be added time losses due to technological progress, structural unemployment, sickness, shortage of materials, legitimate vacations, legal and religious holidays, etc., it may be seen that the insured can establish their future rights to benefits only by putting up a substantial measure of assiduous attendance to work.

\section{Conciliation Statistics}

During the first three months of the current year, the Quebec Conciliation Department looked after 155 conciliation cases for 1959 establishments covering 73,747 employees of which 41,670 were directly concerned. Of these cases, 57 were in the process of settlement at the beginning of January, 1951 and 69 at the end of March, 1951.

These cases have been submitted to the Conciliation Service under the authority of two Provincial laws: The Quebec Labour Relations Act, R.S.Q., 1941, Chapt. 162A, and the Quebec Trade Disputes Act, R.S.Q. 1941, Chapt. 167.

Under the first law, 27 cases concerning 5,240 employees have been submitted regarding new agreements while 82 cases concerning 20,171 employees have been, regarding renewal of agreements. Under the second law, one case concerning 400 employees has been submitted regarding a new agreement, while 10 cases concerning 13,417 employees have been, regarding renewal of agreements and 35 cases concerning 2,442 employees have been, about grievances.

Of these 155 cases, during the first three months of the year, 86 have been settled, of which 54, covering more than 20,491 employees, in a satisfactory manner to the parties; 6 concerning 226 employees, in an indefinite manner and 26, covering 7,325 employees have been referred to arbitration.

All these conciliation cases are divided amongst the various unions in the following manner: Canadian and Catholic Confederation of Labour (CCCL) submitted to conciliation 81 cases, concerning 23,566 employees; The Canadian Congress of Labour (CCL) submitted 18 for 3,910 employees; the Trades and Labour Congress, 10 cases, covering 1,366 employees; the Trades and Labour Congress unions affiliated to the American Federation of Labour (TLC-AFL) 26 cases for 8,686 employees; the Canadian Congress of Labour affiliated to the Congress of Industrial Organizations (CCL-CIO) has submitted 15 cases for 3,510 employees; finally, the local or national independent unions have submitted 5 cases, concerning 632 employees.

In conclusion, we are listing the different subjects submitted to conciliation and the number of cases in which these subjects have been discussed. 
Wages

Duration of labour

Paid holidays

Vacations with pay

Union security

Promotion, transfers, dismissals, lay-offs

The whole agreement

Overtime

Seniority

Holidays

Job classification

Duration and renewal of the agreement
96 Grievance procedure

40 Guaranteed wages

38 Social security (except pension plans)

36 Guarantees of a legal nature

24 Management rights

Jurisdiction

20 Rest periods

20 Purpose

16 Apprenticeship

12

12

In the following table, is to be found the distribution of cases in the various industrial groups.

Denys Dion

Grievances referred to the Conciliation Service of the Quebec Department of LABOUR DISTRIBUTED ACCORDING TO CLASSES OF ESTABLISHMENTS, THE TOTAL NUMBER OF THEIR EMPLOYEES AND THE NUMBER OF EMPLOYEES CONTEMPLATED, FOR THE PERIOD JaNuary to March 1951

\section{Mining}

Manufacturing industries:

Vegetable products

Animal products

Leather and fur

Textiles

Wood and paper

Iron products

Non-ferrous metal products

Non-metallic mineral products

Chemical products

All other products

Electricity

Construction

Transport and communications

Commerce

Finance and insurance

Services

\begin{tabular}{|c|c|c|c|}
\hline $\begin{array}{l}\text { Number of } \\
\text { Conciliation } \\
\text { Cases }\end{array}$ & $\begin{array}{l}\text { Number of } \\
\text { Establish- } \\
\text { ments }\end{array}$ & $\begin{array}{l}\text { Total } \\
\text { employees } \\
\text { in establish- } \\
\text { ments }\end{array}$ & $\begin{array}{l}\text { Number of } \\
\text { employees } \\
\text { affected }\end{array}$ \\
\hline 2 & 2 & 611 & 328 \\
\hline $\begin{array}{r}12 \\
3 \\
15 \\
32 \\
31 \\
15 \\
3 \\
4 \\
3 \\
1\end{array}$ & $\begin{array}{r}14 \\
4 \\
141 \\
3.3 \\
31 \\
16 \\
3 \\
4 \\
3 \\
1\end{array}$ & $\begin{array}{r}5,815 \\
670 \\
4,148 \\
12,875 \\
15,964 \\
7,859 \\
1,130 \\
1,086 \\
1,830 \\
320\end{array}$ & $\begin{array}{r}4,671 \\
139 \\
3,592 \\
4,780 \\
3,411 \\
3,951 \\
1,124 \\
705 \\
868 \\
3\end{array}$ \\
\hline 1 & 1 & 155 & 105 \\
\hline 6 & 765 & 14,964 & 13,297 \\
\hline 4 & 10 & 278 & 186 \\
\hline 7 & 26 & 1,297 & 1,197 \\
\hline 3 & 12 & 235 & 224 \\
\hline 13 & 893 & 4,505 & 3,089 \\
\hline 155 & 1,959 & 73,742 & 41,670 \\
\hline
\end{tabular}

